\title{
Medical errors, apologies and apology laws
}

I n everyday life when an error occurs, disclosure, apology and restitution are expected. In health care when a medical error occurs, disclosure and apology are often overridden by the fear of malpractice litigation.

Full disclosure to the patient is the ethically and professionally responsible course of action. It is also vital for improvement of patient safety and quality of care. ${ }^{1}$ By not disclosing adverse events, the physician fails the patient in terms of honesty, openness and respect. Furthermore, nondisclosure may put the patient at risk for future harms because he or she does not know what happened. Disclosure provides the patient with potentially vital information for making future health care choices and decisions. Candour about errors among colleagues is also critical for professional learning, patient safety improvements and public trust in the health care system.

Offering an apology with disclosure is an important component of addressing medical errors. An apology includes an acknowledgement of the event and one's role in the event, as well as a genuine expression of regret for the patient's predicament. An apology can have profound healing effects for all parties. For the physician, an apology can help diminish feelings of guilt and shame. For the patient, it can facilitate forgiveness and provide the basis for reconciliation. ${ }^{2}$

To address the competing demands between the ethical and safety imperatives of disclosure and apology and the strong instinct to remain silent for fear of inciting malpractice action, apology laws were designed to reduce concerns about legal implications of disclosure and apology. They emerged in the United States in the 1990s as part of efforts to enhance medical error reporting and patient safety. Since then, physicians and hospitals have become more transparent, honest and open with early explanation of unforeseen outcomes. This, as well as early settlement offers by hospitals, has led to a dramatic decrease in malpractice claims. ${ }^{3}$ However, the actual impact of apologies and of apology laws on this outcome is less clear because both are components of broader regulatory and institutional efforts to overcome the complex problem of the silence about medical errors. Furthermore, restitution and early settlement may be an important driver of the reduction in claims. ${ }^{4}$ Countries with nofault compensation systems, such as Sweden and France, experience less frequent complaints.

Under Canada's constitution, the provinces and territories are responsible for liability laws. The first Canadian apology legislation was passed in 2006 by British Columbia ${ }^{5}$ and Saskatchewan, ${ }^{6}$ followed in 2008 by Manitoba. ${ }^{7}$ Ontario and Alberta have since introduced similar legislation. ${ }^{8}$ The protection afforded by apology laws is similar across Canadian jurisdictions.

Some have argued that apology laws are unnecessary to allow health care workers to discharge their professional respon-

sibility toward disclosure and that such laws will make it more difficult for legitimate malpractice claims to succeed. ${ }^{9}$ However, it seems unlikely that apologies would shield physicians in cases of gross negligence. Moreover, the Canadian Medical Protective Association advises that in jurisdictions without apology legislation, physicians "should be aware that the fact that an apology was made and any admission of fault that might have been made during an apology could be admissible in legal or College proceedings related to the adverse event." 10 This statement, designed to protect physicians, threatens to inhibit apologies and supports a code of silence. As a consequence, apology legislation will play an important role in the advice given to physicians faced with a medical error or adverse event and his or her subsequent actions.

Effective disclosure and apology is neither simple nor pain free. Physicians and other health care workers need training in how best to do this when a medical error or adverse event has occurred. They also need a greater awareness of their legal, ethical and professional obligations in this regard. Errors demand a response that simultaneously addresses the needs of the patient, the health care worker and the system. Given the apology-chilling advice from the Canadian Medical Protective Association, the remaining provinces and territories also need to be pressed to enact apology laws.

\section{Noni MacDonald MD MSc}

Section Editor, Population and Public Health

\section{Amir Attaran LLB DPhil}

Associate Editor, Editorials, CMAJ

With the Editorial-Writing Team (Paul C. Hébert MD MHSc, Matthew B. Stanbrook MD PhD, Barbara Sibbald BJ, and Ken Flegel MDCM MSc)

Competing interests: See www.cmaj.ca/misc/edboard.shtml.

\section{REFERENCES}

1. Kaldjian LC, Jones EW, Rosenthal GE, et al. An empirically derived taxonomy of factors affecting physicians' willingness to disclose medical errors. J Gen Intern Med 2006;21:942-8

2. Lazare A. Apology in medical practice: an emerging clinical skill. JAMA 2006;296:1401-4.

3. Geier P. Emerging med-mal strategy: "I'm sorry." Natl Law J 2006:July 24. Available: www.law.com/jsp/article.jsp?id=900005550355 (accessed 2008 Dec. 5).

4. Dresser R. The limits of apology laws. Hastings Cent Rep 2008;38:6-7.

5. Apology Act, SBC 2006, c 19. Available: www.qp.gov.bc.ca/statreg/stat/a/06019_01 htm (accessed 2008 Dec. 5).

6. Evidence Act, SS 2006, c E-11.2, s 23.1(1). Available: www.canlii.org/sk/laws/sta /e-11.2/20080818/whole.html (accessed 2008 Dec. 5).

7. Apology Act, SM 2008, c 42. Available: http://web2.gov.mb.ca/laws/statutes/ccsm la098e.php (accessed 2008 Dec. 5).

8. Silversides A. Apology measures proliferate. CMAJ 2008;179:1115-6.

9. Bailey TM, Robertson EC, Hegedus G. Erecting legal barriers: new apology laws in Canada and the patient safety movement: useful legislation or a misguided approach? Health Law Can 2007;28:33-8.

10. Canadian Medical Protective Association. Apology legislation in Canada: What it means to you [information sheet]. Ottawa (ON): The Association; 2008. 